\title{
TESTIMONIOS ORALES DE LOS DESCENDIENTES DE SIRIO LIBANESES EN SAN MIGUEL DE TUCUMÁN (ARGENTINA). LA IDENTIFICACIÓN ÉTNICA.
}

\author{
Beatriz Vitar Muksdi \\ Consejo Superior de Investigaciones Científicas
}

\section{RESUMEN}

En este artículo se analizan las incidencias de las diferencias religiosas en la experimentación de la etnicidad, entre los descendientes de inmigrantes sirios y libaneses (maronitas, ortodoxos y musulmanes) en Tucumán, Argentina. El análisis se ha efectuado sobre la base de los datos aportados por testimonios orales.

Palabras clave: Argentina, inmigración -sirios y libaneses-, etnicidad.

\section{$\underline{\text { ABSTRACT }}$}

This article analyses the influence of religious diversity on athnic experience among descendants of Syrian-Lebanese Inmigrants (maronites, orthodoxs and muslims) in Tucumán, Argentina. The analysis is based on data obtained by oral testimonies.

Keywords: Argentine, inmigration, Syrian-Lebanese group, ethnicity.

\section{Introduceión}

Los estudios relativos al estudio de la inmigración de origen sirio y libanés en Argentina cobraron gran impulso en los años ' 80 , aunque sin llegar a equipararse a la abundante producción bibliográfica referida a otros grupos migratorios como el español y el italiano, principalmente' ${ }^{1}$. Ahora bien, a pesar de disponer ya

\footnotetext{
' Cíto aquí, a modo sucinto, el repertorio bibliográfico elaborado por W. SULEIMAN: "Los árabes en América Latina: bibliografia preliminar", en Estudios Migratorios Latinomericanos, n. 26, abril 1994, pp. 165-189, del que destacamos los títulos referidos a Tucumán y a la zona Noroeste de Argentina: ALBACA, Elena, "Instalación e influencia del grupo sirio-libanés en el Noroeste argentino" (Mesa Redonda de Folklore organizada por el Museo Folklórico de Tucumán), 1958: JOZAMl, Glagys, "Aspectos demográficos y comportamiento espacial de los árabes en el NOA", Estudios Migratorios Latinoamericanos (en adelante EML), n. 5, Buenos Aires, 1987; PONSATI, Hugo L., Aportes para una reseña de la colectividad árabe tucumana, Sociedad Sirio-Libanesa de 'Tucumán, Tucumán, 1975; SALEH DE CANUTO, M.A. y S. BUDEGUER, El aporle de los sirios y libaneses a Tucumán, Tucumán, 1979; TASSO, Alberto, "Migración e identidad social. Una comunidad de inmigrantes en Santiago del Estero", EML, n. 6-7, ag.-dic. 1987, p. 325) y VELA, M.E. y R. CAIMI, "The Arabs in Tucuman", Asiatic Migrations in Latin America (L.M. Montiel, comp.), México, 1981.
} 
de importantes contribuciones sobre aspectos tales como los mecanismos de llegada, la diversidad religiosa, las formas de asentamiento o el fenómeno de la movilidad espacial y el ascenso económico-social de los migrantes árabes, por citar algunos ejemplos, se carecen aún de estudios específicos sobre la experimentación de la etnicidad entre los descendientes de árabes y más específicamente en lo que concierne a la tercera generación. El marco teórico sobre la problemática de la identificación étnica se asienta en un nutrido conjunto de estudios relativos al caso norteamericano, polarizados en torno a los principios del melting-pot (asimilación completa) y del pluralismo cultural (mantenimiento de los rasgos diferenciales de la cultura de origen), pasando por posturas alternativas como la clásica hipótesis generacional de Marcus L. Hansen², las sucesivas reformulaciones de sus postulados y las críticas a éstos, o por aquellas teorías que formulan la "invención" de la etnicidad". Conforme a los dictados de la ley hanseniana, la primera generación mantiene vivas los valores culturales de origen; la segunda, víctima de un dualismo cultural tiende a practicar un corte con el pasado étnico, mientras que la tercera intenta recuperarlo en un fenómeno designado como revival étnico. Frente a estos principios, que inducen a la consideración de una ruptura generacional drástica, mi análisis atiende al carácter mutante de la identidad conforme a la evolución del propio grupo migratorio, a las interacciones con el medio en el cual se inserta y, en especial, al contexto histórico en que se desarrolla la vida de las sucesivas generaciones de la familia migrante, lo que marcaria diferentes "velocidades" en el proceso de asimilación.

El estudio sobre los descendientes de inmigrantes árabes en Tucumán, se centra en la vivencia de la etnicidad o identidad étnica, entendida ésta como el

\footnotetext{
"Hansen presentó sus famosos postulados acerca del "retorno" de la tercera generación a la etnicidad de origen ("what the son wishes to forget the grandson wishes to remember") en 1938, ante la Sociedad Histórica Augustana, dedicada al estudio de la inmigración sueca en Estados Unidos; esta conferencia se publicó nuevamente en 1952 bajo el título de The Third Generation Americans (V. la reseña de Maria BJERG al libro de Peter KIVISTO y Dag BLANCK, American immigrant an their generations, Studies and commentories on the Hansen thesis after fifty years. University of Illionois Press (Urbana), 1990, en $E M L$, n, 18, ag. 1991, pp. 255-257. Para un análisis crítico de lo que llegó a Llamarse Hansen's law, puede consultarse CECCHI, Camillo, "L' identificazione etnica dei figli degli emigrati", Studi Emigrazione, IV, n. 9, jun. 1967, pp. 210-250), donde se ofrece una completa sintesis acerca de las diferentes teorias surgidas en Norteamérica desde principios del siglo XX, en torno al fenómeno de la identificación étnica dentro de la familia de origen migrante.

'Entre la copiosa bibliografía referida a la cuestión de la etnicidad y al problema generacional, además de los arriba nombrados, cito a modo ilustrativo otros títulos: ALBA, Richard, Ethnic Idenity: The transformation of White America, Yale Univ. Press, 1990; BARTH, F. Los grupos étnicos y sus fronteras, México, FCE, 1976; BÖCKLER, Stefan "Il discorso sull'etnicità nelle scienze sociali italiani e tedesche", Studi Emigrazione, XXXIV, n. 125, 1997; CECCHI, C., 1967 (ob. cit.); CONZEN, Katlleen y MORAWSKA, Ewa, "The invention of ethnicity: una lettura americana", Altreitalie, n. 3, Ap, 1990; LARSEN, B.F. y H. BENDER Y K. VEIN (eds.), On Distant Shores. Proceedings of the Marcus Lee Hansen Immigration Conference, Darles Worlwide Archives, Aalborg (Dinamarca), 1993; SANDBERG, Neil, Ethnicity, Acculturation and Assimilation, 1974.
} 
conjunto de rasgos culturales homogéneos que definen la cohesión de un grupo (origen nacional, religión, lengua, tradiciones, etc.). Arranco así de una concepción dinámica de la etnicidad, según la cual los referentes étnico-culturales del grupo migrante quedan sujetos a negociaciones, en el marco de las interacciones desarrolladas con la sociedad global a lo largo de las diferentes generaciones.

En el caso particular de Tucumán, la colectividad sirio-libanesa, englobada bajo el apelativo homogeneizador de "turco" -debido a que su ingreso al país se produjo cuando Siria y Líbano estaban bajo el dominio otomano- está integrada básicamente por tres grupos religiosos definidos: católicos maronitas (libaneses), ortodoxos cristianos (sirios en su mayoria) y musulmanes (libaneses y sirios), dentro del que predominan los alawítas. En líneas generales, entre los nietos de inmigrantes de estos grupos se observa una revalorización de las tradiciones culturales de sus antepasados, aunque tal proceso se opera desde su condición de ciudadanos argentinos. Ahora bien, en la intensidad y matices de esa adhesión a la etnicidad de origen, inciden tanto el credo religioso de sus padres o abuelos como la posición económico-social alcanzada por la primera generación, factores ambos que obraron como condicionantes en el proceso de asimilación y en la transmisión de la herencia étnica a las generaciones posteriores. En el caso de los libaneses maronitas, dado su mayor grado de occidentalización y su más alto nivel socio-cultural, se produjo una adaptación más acelerada al medio, características que comparten, aunque en menor medida, los sirios ortodoxos. El apego a los valores culturales originarios entre los descendientes de musulmanes -predominantemente sirios- contrasta con el sentimiento étnico de los otros dos grupos, dada la fuerza aglutinante de la religión y, por consiguiente, de la vigencia de la lengua árabe.

Las investigación se desarrolla sobre la base de testimonios orales ${ }^{4}$ recogidos entre hijos y nietos de sirios y libaneses residentes en Tucumán ${ }^{5}$, cuyos ascendientes pertenecen o pertenecieron a los credos religiosos mencionados, sin desdeñar el aporte -cuando es posible- del inmigrante propiamente dicho, dado su gran valor testimonial. A través de entrevistas semi-guiadas, se intenta delimitar las huellas del origen étnico, siguiendo la trayectoria generacional y las diversas etapas vitales de los informantes. De cara a estos objetivos, para la recogida y

\footnotetext{
${ }^{4}$ Sobre el uso de las historias de vida en general, v. La historia oral: métodos y experiencias (Marinas, J.M. y Santamarina, C., eds.). Madrid, 1993. En relación a su uso en los estudios migratorios, véase, por ejemplo, CAVALLARO, Renato, Storie senza siorie. Indagine sull'emigrazione calabrese in Gran Bretagna, Roma, 1981 y "La memoria biográfica. Significado y técnicas en la dinámica de los procesos migratorios", EML, n. 1, dic. 1985, pp. 63-76; FERRAROTTI, F. Storia e storie di vita, Bari-Roma, 1981 y NANCY, Michel, "De las historias y relatos de vida a las prácticas antropológicas: individuos, minorias y migrantes", EML, n. 24, ag. 1993, pp. 205-231.

"También se han recogido testimonios de descendientes de sirios y libaneses que han emigrado a España.
} 
análisis de la información se han delimitado los siguientes aspectos: a) papel de los ancestros en la transmisión de los valores étnicos; b) manifestaciones de la cultura de origen (religión, lengua, tradiciones étnicas, folklore, gastronomía, etc.); c) autopercepción e imágenes recíprocas -sociedad receptora y grupo migrante y d) estrategias de adaptación (matrimonio, inserción laboral y asociacionismo étnico).

\section{a) Transmisión de los valores étnicos}

En lo que respecta a la tercera generación, podemos conjeturar que, a excepción de los descendientes de origen musulmán, el legado recibido se expresa más en términos de una valorización de la experiencia migratoria de los antepasados que en la transmisión de la cultura de origen. De allí que la mayoría de los informantes de origen maronita $u$ ortodoxo posea conocimientos someros acerca del país de procedencia de sus ancestros, reiterándose en los testimonios la común alusión a aspectos tales como la opresión sufrida bajo los turcos, la llegada a Argentina a través de la cadena de llamada, la inserción en el medio a través del comercio ambulante y el escarnio sufrido por los ascendientes bajo el apelativo común de "turco". El principal legado de los inmigrantes es el valor de la gesta migratoria; de allí que la memoria de sus descendientes se centre sobre todo en las peripecias de una larga y penosa travesía hacia América. Un informante, de origen sirio ortodoxo, comentaba acerca del viaje de su padre, junto a otros inmigrantes:

... me imagino que estando un mes en cada sitio, hacinados en la bodega... o en un puerto, tirados asi... como unas ratas... y maltratados.

Estas imágenes también emergen en los testimonios de los musulmanes de segunda y tercera generación ya que más allá del fervor religioso está la condición de inmigrantes de sus antepasados:

Ellos recuerdan ... yo te digo lo que dice mi padre... el tema del viaje en barco, que ha durado muchisimo, que... se han tenido que bancar [sic] hambre y también... cansancio, y qué se yo... decepción también ... porque tenian que hacer ese viaje, que no era lo que habian elegido ellos, pero obligados, forzados $^{6}[\ldots]$ todo eso son malos recuerdos, malos recuerdos... (Y., 35).

\footnotetext{
'El padre de este informante, llegado a Argentina a finales de la década de 1940 , procedía de una nueva oleada migratoria (periodo 1918/20-1945), compuesta principalmente por musulmanes tras la instauración del protectorado francés en Siria y Líbano, que benefició a la población cristiana (Véase al respecto Jorge BESTENE, "La inmigración sirio-libanesa en la Argentina. Una aproximación", Estudios Migratorios Latinoamericanos, $\mathrm{n}^{\circ}$ 9, agosto 1988, Buenos Aires (pp. 239-267),
} 
El viaje se imprime en el imaginario de los hijos y nietos de inmigrantes como la primera expresión del desarraigo y penurias del que emigra; en este sentido, la frase que a menudo se suele usar en Argentina: "los argentinos venimos de los barcos" - quitando los olvidos étnicos que implica- reflejaría el lugar preeminente que ocupa el hecho migratorio en sí dentro de la escala de valores con que se miden los contenidos de la "herencia" de los antepasados. La vivencia migratoria es, pues, rescatada positivamente por los descendientes, en tanto generadora de una predisposición a los movimientos migratorios y de un espíritu pluralista que no reconoce barreras. Esta tendencia sobresale entre quiénes, a su vez, emigraron de Argentina: una tucumana de padre libanés que actualmente reside en Madrid expresaba: "siento que no tengo fronteras, que las fronteras me las ponen cuando me piden papeles" (S., 30). G. (52), hijo de sirios ortodoxos y afincado en Barcelona no dudaba en sintetizar todo el legado paterno en el instante de la despedida, al marcharse de Tucumán: "Mi padre me ha transmitido el sentimiento hacia el inmigrante [...] me dio un abrazo y me dijo "adelante" [...]. A esos 60 ó 70 años que él había vivido como inmigrante, me lo transmitió en cuatro segundos".

El proceso de inserción del árabe en Argentina, iniciado con la esforzada venta ambulante para luego escalar social y económicamente? es apreciado como muestra de su capacidad de adaptación, virtud que forma parte de esa "cultura del inmigrante" que señalara un informante. Una descendiente de libaneses lo resumía en unas pocas palabras: "el árabe que salía a vender en la calle y después tenía el hijo doctor, era para también [sic] insertarse en el medio de otra forma" (M. E., 45).

Con respecto a los descendientes de musulmanes, la herencia étnica está marcada por la religión, aunque tal vivencia puede estar matizada por el sexo y el statu generacional. Un hijo de sirio alawíta, no obstante admitir la falta de un conocimiento sólido de la lengua árabe (indispensable para las funciones del culto), apreciaba en sumo grado los valores religiosos heredados, expresando su propósito de mantener vivo dicho legado para transmitirlo, a su vez, a las generaciones venideras:

La práctica [de la religión islámica] sigue. Nosotros... [él y sus hermanos] por lo general entendemos todo, mucho, pero hablamos poco. $Y$ por eso la herencia ésa [de la cultura de origen], si no fuera por eso, sería un cien por cien. Lo hemos asumido, lo hemos heredado y tratamos de seguir así, para que los hijos hereden también eso.

\footnotetext{
${ }^{7}$ De gran interés para un análisis comparativo es el estudio sobre la inmigración árabe en Brasil realizado por Osvaldo TRUZZI, De mascates a doutores: sirios y libaneses en Sao Paulo, S. Pablo, 1992.
} 
Otro de los aspectos inculcados por el inmigrante a sus descendientes es el "agradecimiento" a la sociedad de acogida, sentimiento derivado de la circunstancia de ser ésta la patria de sus hijos. No obstante forma parte también de las estrategias de adaptación -bien podemos llamarlas negociaciones ${ }^{8}$ desplegadas sobre todo por los migrantes que ingresaron al país en una etapa (finales de la década de 1920) en la que el Estado intentaba aplicar medidas restrictivas a la inmigración, especialmente aquélla "no deseada"". Nacida al abrigo de la posición más o menos cómoda alcanzada por el árabe en el medio tucumano, tal gratitud emerge en el discurso de la primera generación, obviando las alusiones a cierta discriminación o rechazo que, en contraste, sí aparecen en los testimonios de sus herederos. Una nieta de libaneses maronitas deja constancia de que su abuela

... sentía una cosa muy tremenda en esta sociedad [Tucumán], porque eran los árabes muy discriminados [...] los hacían muchísimo de menos... [...] Cuando veían un árabe decían "perro, perro, perro..." como no entendían el idioma... (M., 44).

Otra informante, hija de un sirio alawíta, luego de oír a su padre afirmar, al comienzo de la entrevista ${ }^{10}$, de que "Argentina daba la entrada [sic] a todos los que querían trabajar", le incitaba a recordar las circunstancias de su ingreso al país hasta "arrancarle" el relato de las peripecias vividas:

Cuando entramos nosotros [el inmigtante y un pariente]... primero entramos al Brasil. No me dejaban entrar a la Argentina y... lo han prohibido. Y un paisano" de San Pablo, Brasil, ha hecho la diligencia... trabajaba con el Consulado francés; hacían pasar gente. Por intermedio del embajador francés, pasaban gente... (A., 90).

El papel de la segunda generación en la reivindicación de los valores culturales de origen no se percibe como un hecho relevante, debido a la presión del proceso de adaptación a la sociedad local, dando lugar a la transmisión de un sentimiento vergonzante en relación al origen étnico. Este malestar habría sido experimentado sobre todo por los libaneses maronitas y sirios ortodoxos; así, M.E. expresaba:

\footnotetext{
${ }^{8}$ Con relación a estas formulaciones, v. K. CONZEN y E. MORAWSKA, 1990 (ob. cit.).

"Véase al respecto Jorge BESTENE, "Entre el discurso y la acción: la política migratoria argentina y la inmigración de sirios y libaneses", Studi Emigrazione, XXXII, n. 118, 1995 ( pp. 263-275).

${ }^{10}$ El castellano hablado por A.T. ( 90 años) denota aún algunas deficiencias. La entrevista se realizó de modo conjunto a este inmigrante, a su esposa (73) y a dos de sus hijos, C.T. (psicóloga, 52) y S.T. (estudiante de Derecho, 26). Los miembros restantes de la familia (la menor de las mujeres y el hijo mayor) se encontraban ausentes.

"Como bien recuerda E. BIONDI ASSALI ("L'insertion de groupes de langue arabe dans la société argentine", Renue Européene des Migrations Internationales, vol. 7, n. 2, 1991, pp. 139-151), "paisano" es un término aceptado unánimemente por los inmigrantes árabes, frente a la denominación de "turcos" rechazada rotundamente por sus connotaciones negativas.
} 
... Cuando estaba en la [escuela] primaria, o en la secundaria... era que en algo me daba como cosa ${ }^{12}$ [sic] ser árabe, pero ¿por qué?. Porque me lo transmitió mi madre.

La debilidad de la herencia étnica se acentúa en el caso de los nietos o hijos de inmigrantes que proceden de matrimonios mixtos (árabes o descendientes de éstos con personas de otro origen), desencadenando un cierto interés por el origen étnico, especialmente por aquella vertiente que ha sido objeto de censura; una informante que obedece a este perfil da cuenta de estas "tensiones" étnico-culturales en el seno de su familia:

Mi abuela materna siempre ha sido una figura... mi abuela materna, la de origen español, siempre ha sido una figura importantísima en la familia y mi padre [hijo de libanés musulmán] ha sido el turco de la fámilia y por esa razón ha sido el ogro de la familia ¿no? Entonces, siempre ha habido ahí una pugna entre... las costumbres... las culturas árabe... y española $[\ldots]$ Lo árabe estaba muy contaminado... de todo. [...] Ahora tal vez... que estoy lejos y... un poco he intentado reconciliarme con mi pasado familiar y puedo dialogar con mi padre desde otro lugar (S.).

\section{Manifestaciones de la cultura de origen}

\section{- La práctica lingïística:}

La lengua es el campo donde con mayor nitidez se manifiesta la necesidad de adaptación del inmigrante y la de sus descendientes. Así, para contrarrestar la imagen exótica ${ }^{13}$ del grupo árabe en la sociedad argentina, desde los inicios de su inmigración se instauró la práctica del cambio de apellido, apelando generalmente a su traducción castellana; decisión ésta que ocasionaba a veces un corte radical con el pasado, resultando una herencia traumática para los descendientes: "quedó como algo familiar [...] diciendo siempre ¿por qué no lo cambiamos? [E1 actual] no es muestro apellido. Es como que estaba siempre en el ambiente familiar [...] pero nadie hizo nada por cambiarlo" (M., nieta de libanés musulmán).

\footnotetext{
${ }^{12}$ Expresión coloquial utilizada en Tucumán para expresar reticencia hacia algo.

1. Como tal clasificaba Juan Alsina -Director de la oficina de Inmigración en 1910- al inmigrante "turco" dedicado al comercio ambulante, contrariando las expectativas del Estado argentino, que prefería al "peón agrícola, jornalero o asalariado urbano", según los requerimientos del modelo agroexportador en auge V. Jorge BESTENE, "Dos imágenes del inmigrante árabe: Juan A. Alsina y Santiago M. Peralta", EML, n. 36, agosto 1997 , p. 290.
} 
El uso de la lengua es objeto de autocensura en el caso de hablantes bilingües de segunda y tercera generación. La mayoría de los informantes de origen maronita u ortodoxo coincide en señalar que hablar el árabe "era como un... casi un desprestigio" (G.) en un medio de castellano-hablantes, donde se hacía mofa del uso incorrecto de consonantes, en especial la pronunciación de la "be" por la "pe"; en el inconciente colectivo, se asociaba esta deficiencia al ejercicio del comercio ambulante, practicado por el árabe en los inicios, ofreciendo aquí y allá "beines" y "beinetas". Una descendiente de libaneses expresaba: "Por ejemplo, cuando yo iba a la [escuela] secundaria no quedaba bien hablar en árabe. Hablar el árabe no es lo mismo que hablar el inglés"14 (E., 43 años).

Entre los descendientes de musulmanes, especialmente entre los varones, el uso de la lengua se mantiene vigente por la práctica religiosa; su grado de perfeccionamiento va correlativo al futuro desempeño de funciones importantes dentro del culto, como ocurre con los hijos de un sheik o sacerdote: "[La lengua árabe] es fundamental para entender la religión [...] Mi abuelo matemo, él me enseñaba [...] Cuando tenía 4 ó 5 años me ponían delante de los paisanos, las recitaba" (S., 26 años). La hermana del informante lo corroboraba, completando la frase de este informante: "Repetía las suras completas del Corán que mi abuelo le enseñaba, se las aprendía de memoria" (C., 50).

La lengua es uno de los elementos que la tercera generación intenta recuperar, siendo casi inexistente su conocimiento entre los descendientes de sirios cristianos y libaneses maronitas; la progresiva pérdida del idioma se origina también en los matrimonios exogámicos practicados por la segunda y tercera generación. Salvo casos aislados de dominio completo o parcial del árabe, la mayoría de los entrevistados manifiesta su deseo de aprenderlo, aunque este afán de conocimiento parece obedecer más bien a un interés básico por los "idiomas" que a su valoración como rasgo étnico.

\section{-Vivencias religiosas:}

Las diferencias religiosas que caracterizaron a los migrantes sirios y libaneses constituyeron, conjuntamente con su origen regional o aldeano, los ejes

\footnotetext{
${ }^{14}$ Debe recordarse aquí que la política migratoria argentina apuntaba a fomentar la inmigración europea (tal como lo estipulaba el art. 25 de la Constitución Nacional de 1853), preferentenente de origen nórdico (V. al respecto Maristella SVAMPA, "Inmigración y nacionalidad: el caso de la Argentina, 1880-1910", Studi Emigrazione, XXX, n, 110, 1993, pp. 289-309).
} 
estructuradores de su identidad. La identificación étnico-religiosa ${ }^{15}$ ofrece cierta continuidad entre los descendientes, como reflejo del rol que tales indicadores jugaron en el pasado; no obstante, las diferencias de credo suelen minimizarse frente a la sociedad global. En el ámbito religioso se destaca la tendencia de los libaneses a diferenciarse del resto, aunque de modo más sobresaliente del grupo islámico, cuya práctica religiosa resulta ajena a un país de tradición católica como Argentina. Así también, los descendientes que cuentan entre sus ancestros tanto a sirios ortodoxos como a libaneses maronitas, se inclinan a identificarse como libaneses; ello se explica en función del mayor prestigio de este grupo migrante (del que formaban parte, en su origen, destacados intelectuales y profesionales) y sus costumbres más occidentalizadas, además de resultar más afines a la sociedad local en su condición de practicantes católicos. Una informante con las características arriba señaladas (de padre maronita y madre ortodoxa), afirmaba con rotundidad: "Mi identificación religiosa es con lo maronita. Yo me identifico como libanesa, con el modo de vida de la gente libanesa" (E.).

La identificación con el grupo religioso de origen es más acentuada entre los musulmanes, cuyos descendientes muestran un gran celo en la defensa de las tradiciones islámicas, en especial en el caso de pertenecer a una familia de sacerdotes o sheiks (función de carácter hereditario): $\mathrm{Y}^{16}$, hijo de un sacerdote sirio alawíta, narraba su vivencia de la religión:

Yo te diría que la religión, el Islam, es un medio de vida. Así que sí o sí la religión está ligada con la sociedad... lo social con lo religioso es una sola cosa. Nosotros acá, por ejemplo, cuando muere alguien, suena el teléfono en mi casa a la hora que sea y voy con mi papá a cumplir con los ritos musulmanes.

La religión es también factor de cohesión y de fuerza para el grupo étnico; otro informante de origen musulmán decía de su padre que "siempre ha estado fomentando la unión, y que no nos olvidemos de la religión, de la gente. A la gente... se refiere a la gente de la colectividad, principalmente" (S.).

\footnotetext{
${ }^{15}$ Para estas cuestiones, véase Gladys JOZAMI, "Identidad religiosa e integración cultural en cristianos sirios y libaneses en Argentina, 1890-1950", EML, n. 26, abril 1994, pp. 95-111 y también Pablo SAPAG M. DE LA P., "Los cristianos sirios. Una visión integradora del mundo árabe", Actas de las II Jornadas Internacionales de Jóvenes Investigadores en Ciencias de la Información (Univ. Complutense de Madrid), 1995, pp. 21-30.

${ }^{16}$ Durante la entrevista realizada en agosto de 2000 , este informante destacaba la importancia del grupo alawíta en Tucumán haća "treinta o cuarenta años atrás", en que "habia... por lo menos cien sacerdotes que podian oficiar una misa; en este momento hay seis. Seis de la linea... de la élite [...] Mi papá es sacerdote, es uno de los seis de los que te estoy hablando".
} 
El sentimiento religioso de los descendientes islámicos contrasta de modo notorio con el experimentado por los hijos y nietos de sirios ortodoxos y libaneses maronitas, muchos de los cuales, además de haberse educado en colegios católicos, no atestiguan práctica religiosa alguna.

\section{- Valoración de la cultura originaria:}

Los descendientes de árabes, cualesquiera sea el credo religioso de sus ancestros, aprecian de modo superlativo la pertenencia de éstos a una "civilización milenaria"; es un valor que se esfuerzan por remarcar como contrapeso a un discurso oficial, al modelo liberal de homogeneización de la población y a programas escolares que ignoraron el rol histórico de la inmigración, sobre todo la árabe, en la conformación de la nacionalidad argentina. Como bien lo apuntaba una informante, "no se ha hecho fiestas especiales, en el colegio ... ni se ha hablado de todo eso... Yo creo que ha sido una política bastante... dura de asimilación" (S.).

Entre los hijos y nietos de libaneses, en especial, es frecuente la alusión a la riqueza y aportes de la cultura fenicia, reivindicada por sus mayores como elemento de lustre dentro del bagaje cultural aportado al país receptor ${ }^{17}$. Los inmigrantes musulmanes transmiten también a sus hijos ese orgullo por la "antigüedad": un inmigrante sirio afirmaba que "Alawí [los alauitas], es la primera raza que se ha hecho en el planeta [...] Siria es más antes que todos [sic]" (A.); comentario éste que era rematado no sin ironía por su hija: "Yo creo que siempre ha estado la fantasía ésta de que uno... el nuestro es... el pueblo elegido" (C.).

Como valor destacado de la tradición árabe, cultivado sobre todo por la primera generación, se incluye la solidaridad de la familia extensa, rasgo éste que, si bien es compartido por todos los grupos religiosos, se halla más acentuado entre los musulmanes, junto con una fuerte valorización de la figura paterna. Un hijo de musulmanes comentaba que su padre, ya anciano, ante el temor a una muerte próxima, "me ha buscado a mí o a mi hermano [...] y empieza a dar recomendaciones: que yo la cuide a mi hermana [...] a mi sobrino [..], de ayudarla a mi tía" (S.). El rasgo patriarcal no es un elemento predominante en la vida fami-

\footnotetext{
${ }^{17}$ Los descendientes de libaneses, en ocasión de celebrar el centenario de la inmigración árabe en Argentina, rindieron un homenaje a "sus ancestros los Fenicios, pioneros de la universalización de la cultura", según reza junto a la fotografía del Monumento al Alfabeto que levantó dicha colectividad en San Miguel de Tucumán, capital de la provincia de este nombre V. Cien años de historia de la inmigración sirio-libanesa, 1890-1990, publicación de FEARAB (Federación de Entidades ArgentinoÁrabes) Tucumăn, 1990, p. 127.
} 
liar de los libaneses, según el testimonio de M.E., que reconoce en la abuela materna el papel de transmisora de las costumbres y valores tradicionales: "nosotros éramos dieciocho nietos y todos nos juntábamos alrededor de la abuela, en las siestas [...], tanto sus hijos como toda la familia, en una mesa de casi cuatro metros a tomar el café árabe".

A su vez, una descendiente de libaneses musulmanes, de padres separados, decía que "mi padre cada vez que venía a vernos... era [sic] visitar a toda su familia, a sus tíos [...] éramos de la familia, vivimos todos en Tucumán y teníamos que vernos" (S.).

\section{Los inmigrantes árabes y el medio argentino: visión de los otros y autopercepción}

Dos factores singularizaron la inmigración árabe, confabulándose ambos en la percepción que de ellos tuvieron la sociedad de acogida y otros grupos migratorios. En primer lugar, su arribo más "tardío" en relación a los contingentes del Viejo Mundo, lo que acentuaba la condición de advenedizo, común a todos los inmigrantes. En este aspecto, desde un mayor arraigo y asimilación, los integrantes de otros grupos tienden a manifestar recelo hacia los inmigrantes más recientes; así, G. opinaba que "los que más tarde llegaron, son los que más se rechazaban". Incluso dentro de un mismo grupo étnico, los ya radicados -desde la ventajosa situación de dominio del idioma, por ejemplo- podían llegar a marcar sus diferencias respecto de los recién llegados o de los procedentes de un arribo más tardío.

En segundo lugar, debe agregarse la imagen difundida durante largo tiempo en la sociedad argentina acerca de la inconveniencia de una población "exótica", "inútil" y poco deseable para las metas del Estado liberal y para el modelo agroexportador vigente, que no ocultaba sus preferencias por el campesinado europeo frente a unos migrantes que ejercían el comercio autónomo, partiendo de la precaria venta ambulante hasta llegar a la empresa comercial o industrial. Se arraigaron así los prejuicios contra el "turco comerciante"18 que persiguía el enriquecimiento, percepción negativa que la segunda y tercera generación buscarán desterrar mediante los estudios superiores y la inserción profesional.

\footnotetext{
${ }^{18}$ Sostiene Georg Sinmel que "En la historia de la economía, el extranjero aparece como comerciante, o, si se quiere, el comerciante aparece como extranjero" (citado por A. TASSO, 1987, ob. cit., p. 325).
} 
Los descendientes denuncian sin resquemor el rechazo experimentado por sus abuelos o padres: "Acá el árabe ha sido muy discriminado" (E., nieto de libaneses). Otros lo extienden también a toda la población de origen no europeo: "Había un prejuicio, pero no solamente con lo árabe [...] los japoneses, chinos, los judíos... o los árabes no se les daba mucha importancia. Eran de segunda. Ciudadanos de segunda" (G.).

La común denominación de "turco" dada a los diversos grupos árabes es asumida por la tercera generación, aunque su aceptación está condicionada al contexto en el que se emite tal apelativo. Los estereotipos que a su vez el inmigrante acuñó en relación a la población local y a otros grupos migratorios, se transmite de una generación a otra. La percepción del criollo (elemento nativo) como un ser indolente y sin espíritu de progreso, resentido por el ascenso de quienes vienen de fuera, se refleja en el discurso de los descendientes de sirios y libaneses, sin distinción de origen religioso; la persistencia de esta imagen podría clasificarse como herencia étnica, ya que tanto el hijo como el nieto de inmigrantes reconoce en sus logros profesionales el esfuerzo de sus abuelos y padres. Un informante de origen musulmán (segunda generación) refleja esta visión estereotipada del nativo:

[Los árabes] han trabajado muchísimo... ellos [los criollos] veían como progresaban los turcos... Y los criollos seguían en lo mistno; para ellos trabajar de lunes a viernes implicaba un descanso de sábado y domingo, tomándose toda la ganancia en vino (Y).

Según el testimonio de una nieta de libaneses: "[el criollo] se pasaba mirando el horizonte bajo la arboleda, pero sin hacer nada [...] quería tener todo sin hacer nada" (M.E.).

A su vez, los libaneses remarcan sus diferencias con respecto a los descendientes de inmigrantes islámicos; una hija de libaneses, comentaba acerca de un amigo de origen alawíta: "Él es musulmán. Él tiene una visión diferente, porque nosotros es como que nos adaptamos y ya en la tercera generación, yo te diría, yo ya me siento muy argentina" (M.). La persona aludida, a quien se entrevistó posteriormente, se autodefinía a su vez como "argentino de raza semita... con una inclinación profunda hacia las costumbres árabes... bien oriental, con costumbres orientales y con el pensamiento oriental también" (Y.).

Con relación a otros grupos étnicos, el discurso de los descendientes de maronitas y ortodoxos pone el acento en la capacidad adaptativa del árabe y en su sociabilidad: "es el que más se adaptó al medio éste... rápido se vistió de gaucho... rápido hizo de amigos... por ejemplo, yo me acuerdo de la casa de mis 
abuelos, siempre abierta para todo el mundo" (M.E., nieta de libaneses). Por su parte, una hija de sirios ortodoxos afrimaba que su padre "nunca se sintió ajeno a Argentina. Y a pesar de que tenía sus problemas de idioma" (E.).

Por lo general la experimentación de la alteridad por parte de la segunda y de la tercera generación se produce durante la etapa escolar primaria o básica: los testimonios dejan traslucir la existencia de una "diferencia", que no llegaba sin embargo a producir discriminación o hechos que pudiesen irritarles en su condición de hijos o nietos de inmigrantes. Por lo demás, debe señalarse que, en el ámbito escolar, la historia oficial referida a la construcción de la nación exaltaba la cruzada civilizadora contra la "barbarie" indígena-realizada por los españoles y sus descendientes criollos- pero silenciaba el aporte inmigratorio ${ }^{19}$ de los grupos "indeseables"; esto dio lugar a un proceso de autodiscriminación, tal como lo sugiere el relato de M.E.:

Me sentía diferente al resto. Y aparte como yo tengo los rasgos [árabes] muy marcados, claro. Yo pienso que cuando era pequeñita... [...] siempre me decían [...] "sos [eres] árabe"... y ya me molestaba, porque en realidad yo quería ser más rubita, más parecida al resto [...] me acuerdo que renegaba cuando era chica y cuando era adolescente [...] porque era una cosa muy tremenda [...] yo parecía que era venida [sic] de allá.

Esta sentimiento de la diferencia tiende a reducirse en la etapa de educación media, al tiempo que en la universitaria, sobre todo durante la última dictadura, pasa a diluirse bajo las connotaciones dramáticas de la represión, que afectó en especial a los centros de estudios superiores; en ese contexto, cualquier prejuicio étnico (hacia sí y para con los otros) que pudiese generarse desaparecía bajo el imperativo de la cuestión ideológica; M.E., con un familiar desaparecido, decía acerca de su etapa universitaria: "estábamos muy marcados por esa dictadura [...] ha sido muy fuerte esa época para mí $[. .$.$] la veo como una época oscura [\ldots]$ entonces no sé si me importaba ser árabe o no árabe".

Colocándose a distancia de la sociedad de acogida, más o menos notoria según el origen religioso, en los testimonios aparece un "nosotros" (los inmigrantes y sus descendientes) frente a los "otros" o "ellos" (los argentinos). Por ejemplo, un hijo de musulmanes comentaba:

${ }^{19}$ Véase STAMPA, 1993 (Ob. cit.). 
Por ahí con nosotros hay una diferencia, no una diferencia que ellos la hagan, de decir: "bueno, vos que sos [eres] árabe...", sino la diferencia por los temas de las guerras, por el tema de los problemas religiosos de Medio Oriente"20 (S.).

Ante situaciones internacionales de conflicto, se pone de manifiesto cierta sensibilidad étnica ${ }^{21}$, tal como lo sugiere el testimonio anterior. Una informante (hija de musulmanes alawítas y residente durante algún tiempo en España) corrobora esta predisposición, a la que se suma también el matiz religioso:

... la sensibilidad por lo árabe está ahí.. es decir, está en mí... A mí, cuando yo en España... cuando era el furor de la guerra del Golfo, yo no tenía demasiados datos de quién era Sadam Hussein, pero... no le creía nada al bando contrario... Es decir, era una aliada natural [...] Cuando la guerra de los Seis Días en Israel, que yo era jovenzuela... [... ] siempre... hay como una especie de sensibilidad proclive a lo árabe... Y cuando fue la guerra de Irán e Irak, bueno... más del lado de los irakíes que de los iraníes, que son chiitas... (C.T.).

\section{Estrategias de adaptación}

\section{- Matrimonio:}

Los miembros de la tercera generación por lo general contraen matrimonio fuera del grupo, en contraste con la segunda generación, que experimenta la presión paterna en torno a la práctica endogámica, de cara a reforzar la comunidad étnica. En la tendencia exogámica de la tercera generación influye la inserción laboral y profesional plena de sus miembros; una mujer soltera, de padre libanés y madre de origen sirio (segunda generación), que afirmaba tener una "vida profesional exitosa", expresaba sus preferencias matrimoniales:

A mí nunca me gustaron los hijos de árabes. Yo soy argentina. Los posibles candidatos árabes me resultaban ajenos [...] Nunca me han gustado los paisanos como maridos (E.).

Las descendientes de árabes suelen hacer referencia al carácter "machista" de sus pares masculinos y también a la tendencia a las relaciones poligámicas de los árabes en general. Una informante de ascendencia libanesa y española, decía

\footnotetext{
2" Otro informante de origen alawíta (segunda generación) explicaba las razones del seguimiento estrecho de la evolución política de Siria, tras la muerte de Hafed el Assad (del mismo credo religioso) en 2000: "nosotros teníamos expectativas, en cuanto a quien le iba a suceder en el mandato porque, sinceramente, si cambiaba de mando, ibamos a volver con los problemas religiosos".

${ }^{21}$ En el momento de realizar esta entrevista (enero de 2000), aún no se habian producido los bombardeos aliados a Afganistán, tras el ataque contra las torres gemelas de Nueva York.
} 
que su padre "solía andar con otras mujeres, entonces eso era ya visto como la cultura árabe [...] como mi padre es así, él es un polígamo"; circunstancias éstas que alimentan sus recelos hacia el hombre árabe: "yo no sé si podría vivir en un país como... árabe, con unas tradiciones... bastante fuerte... y de la posición que ocupa la mujer; yo creo que no podría" (S.).

Dentro del grupo musulmán se observa una marcada inclinación hacia el matrimonio dentro de la comunidad religiosa e incluso hacia las uniones con parientes próximos: un descendiente de musulmanes, casado con su prima, perteneciente también a la comunidad alawíta, confesaba que a la hora de elegir esposa un hombre de dicho credo, "no sólo se prefiere que sea de la comunidad sino también de la familia". No obstante, existe cierta flexibilidad ante el matrimonio masculino extra-comunitario, en tanto que en su condición de herederos y transmisores de las tradiciones religiosas, los varones tenderán a incorporar a su cónyuge a la práctica islámica; un hijo de musulmanes comentaba: "Yo estoy de novio con una chica que es española, descendiente de españoles. Y ella va a las reuniones religiosas porque yo no me he abierto de lo mío, sino que he tratado de sumarla a ella" (S.).

No sucede así con las mujeres de origen musulmán, cuya boda fuera del círculo religioso de pertenencia se considera como una pérdida para el grupo, razón por la cual se tiende a promocionar su participación en las asociaciones étnicas, especialmente las juveniles, para reforzar los lazos ćtnico-sociales. S. explicaba que "la crítica [al matrimonio exogámico] no va a que te has casado con una católica, sino a que... a que sos [eres] uno menos de la colectividad".

Por lo demás, la práctica de uniones matrimoniales exogámicas por parte de miembros de la segunda y tercera generación conlleva al debilitamiento de la familia extensa y de las redes de solidaridad tejidas en tomo a la misma, rasgos éstos que en el pasado jugaron un papel importante como elementos distintivos del grupo étnico.

\section{- Asociacionismo étnico:}

Por lo general se observa la casi nula participación de la tercera generación de sirios ortodoxos y libaneses maronitas en las instituciones fundadas en el pasado para promover la solidaridad étnica (Sociedad Sirio-Libanesa y Casa Libanesa): "Mi abuelo sí [asistía a dichas sociedades]. Y después que se murió mi abuelo, como que se terminó, se murió" (M.E.). La falta de interés de los descendientes por las instituciones étnicas es un reflejo de la pérdida de vigor de las 
mismas, en el marco de la adaptación de las sucesivas generaciones al medio argentino. Una excepción es la sociedad que congrega a los musulmanes (Asociación Cultural Panislámica) que, además de promover eventos culturales, es escenario de actos religiosos celebrados semanalmente; la entidad contribuye así a la reafirmación étnico-religiosa., la que en los sectores jóvenes se complementa con el desarrollo de actividades recreativas. Un hijo de musulmanes resaltaba la importancia de esta asociación y la necesidad de crear otras en el interior de la provincia para "que no vayas [sic] perdiendo lo que es la religión... y la cultura [...] yo, dentro de la palabra religión junto todo: cultura, la lengua, la sociedad en sí... qué sé yo... hasta los entretenimientos" (S.).

\section{- Inserción laboral:}

Los informantes aprecian como uno de los mayores legados del inmigrante a las nuevas generaciones la posibilidad de acceder a la educación, considerada como la vía más sólida para la inserción plena en el medio receptor. Entre los miembros de la tercera generación, integrada en su mayoría por personas con formación universitaria, se detecta que esta vía les ha permitido -como ocurre a veces con la segunda generación-alcanzar una situación próspera y el reconocimiento social:

Acá es como que te tenías que ganar un espacio, un lugar. Y creo que el árabe, en eso, acá se ha superado bastante [...] de aquí han salido filósofos, ministros. Lo profesional es como que los ha levantado (M.E.).

Esta inserción da lugar a que tanto la segunda como la tercera generación participe también de otros valores culturales, coadyuvando a desterrar la imagen del "turco" mercachifle inclinado al juego y sólo apto para amasar dinero. Una hija de sirios ortodoxos, se hallaba promoviendo, a mediados de los '90 la fundación de una asociación de jóvenes profesionales de origen sirio y libanés para mostrar a la sociedad tucumana "que no sólo somos unos turcos timberos" Ch.).

\footnotetext{
${ }^{22}$ La expresión alude a cierta afición por los juegos de cartas con que los árabes amenizaban sus citas cotidianas en la Sociedad Sirio-Libanesa. La imagen del "turco timbero" se halla muy extendida en Tucumán.
} 


\section{Conclusiones}

Los estudios desarrollados hasta ahora permiten avanzar algunas consideraciones acerca del fenómeno de la identificación étnica, según los datos aportados por los testimonios aportados por informantes pertenecientes a los diversos credos religiosos. La valoración de ciertos contenidos de la cultura de origen entre los descendientes de sirios y libaneses se perfila como un fenómeno que se opera desde una situación de éxito profesional y de adaptación a la sociedad de acogida. La áfirmación de la identidad en el caso de los hijos y nietos de maronitas y ortodoxos descansa sobre aquellos rasgos culturales que no ofrecen fricciones con las costumbres locales. Entre las personas de origen musulmán, los valores étnicos consagrados en torno a la religión se hallan plenamente arraigados, aunque determinados moldes de comportamiento de la sociedad global han sido incorporados a lo largo del proceso de asimilación.

La herencia étnica se materializa en la valoración de todo un conjunto de estrategias de adaptación que el inmigrante desplegó en la sociedad receptora, movido por su "instinto de supervivencia", según lo definía un informante. Los descendientes de sirios y libaneses en Tucumán ostentan como legado la gesta heroica de la migración de sus ancestros, su capacidad de asimilación e inserción en el país de acogida y la experimentación de una conciencia pluralista como un valor que los enorgullece y los vuelve proclives a derribar las fronteras étnicoculturales que desgarran hoy a la humanidad. 